\title{
Upaya Meningkatkan Hasil Belajar Kognitif Melalui Pembelajaran Berbasis Praktikum Ditinjau Dari Kemampuan Akademik Mahasiswa
}

\author{
Fahruddin $^{1}$, Bakhtiar ${ }^{2}$ \\ 1,2Program Studi Pendidikan Biologi, STKIP Bima. Jalan Piere Tendean Kel. Mande Tel. Fax (0374) \\ 42801, Bima 84191, Indonesia. \\ Email: bangfenmbozo@gmail.com
}

\begin{abstract}
Abstrak
Jenis penelitian ini adalah penelitian tindakan kelas (PTK). Adapun rancangan penelitiannya yaitu melalui empat tahap dari setiap siklus yaitu dimulai tahap perencanaan, pelaksanaan, observasi/evaluasi, dan refleksi. Penelitian ini bertujuan untuk mengetahui: 1) Peningkatan hasil belajar kognitif melalui pembelajaran berbasis praktikum pada mahasiswa pendidikan Biologi tahun akademik 2017/2018. 2) Peningkatan hasil belajar kognitif ditinjau dari kemampuan akademik mahasiswa. Subyek penelitian adalah seluruh mahasiswa semester IV kelas A yang berjumlah 30 orang. Instrumen penelitian ini adalah berupa soal tes dengan bentuk soal pilihan ganda, yang terdiri dari 20 soal. Penelitian ini dihtung berdasarkan rumus ketuntasan individu dan klasikal, kemudian dilanjutkan dengan uji N-Gain. Berdasarkan hasil perhitungan dengan menggunakan rumus Ketuntasan Individu dan Ketuntasan Klasikal, maka proses pembelajaran siklus II mencapai peningkatan dengan 29 orang berkategori tuntas, dan dinyatakan tuntas secara klasikal dengan perolehan nilai sebesar 96,66\%, maka diperoleh kesimpulan bahwa hasil penelitian menunjukkan: 1) Ada peningkatan hasil belajar kognitif melalui pembelajaran berbasis praktikum. 2) Ada peningkatan hasil belajar kognitif ditinjau dari kemampuan akademik mahasiswa melalui pembelajaran berbasis praktikum dengan persentase mahasiswa berkemampuan tinggi sebesar 46,67\%, sedang sebesar 43,33\%, dan rendah sebesar 10\%. Menurut hasil uji N-Gain 46,67\% berkategori tinggi, dan 53,33\% berkategori sedang, yang berarti peningkatan hasil belajar kognitif sangat baik.
\end{abstract}

Kata Kunci: Pembelajaran berbasis praktikum, Hasil belajar kognitif, Kemampuan akademik

\section{PENDAHULUAN}

Berisi latar belakang, rasional dan/atau urgensi pene Menurut Direktorat Akademik (Dikti.2008) bahwa Pola pembelajaran di perguruan tinggi yang berlangsung saat sekarang perlu dikaji untuk dapat dipetakan pola keragamannya. Oleh karenanya perlu dilakukan perubahan dalam proses dan materi pembelajaran di perguruan tinggi tidak lagi didomonasi dengan pola pembelajaran berbentuk Teacher-Centerad-Content-Oriented (TCCO). Pola pembelajaran yang berpusat pada pendidik atau TCCO merupakan pembelajaran konvesional yang dapat memberikan dampak negative pada mahasiswa di antaranya mahasiswa menjadi pasif, kurang kreatif dan jika mengandalkan penjelasan dari pendidik saja, maka informasi yang akan diterima sangat terbatas dan bisa menurunkan nilai hasil belajar mahasiswa. Salah satu upaya untuk meningkatakan mutu pendidikan tersebut yaitu dengan melakukan perbaikan pada proses belajar mengajar di kelas dengan pola pendekatan pembelajaran berpusat pada 
siswa atau bergeser kepada prinsip StudentCentered-Learning (SCL), dengan menfokuskan pada tercapainya kompetensi mahasiswa yang bermandiri dan berkompeten. Hal ini berarti mahasiswa harus didorong untuk memiliki motivasi dalam diri mereka sendiri, kemudian berupaya keras mencapai kompentensi yang diinginkan (Fahruddin, 2014).

Dalam rangka meningkatkan mutu pendidikan dan mencerdaskan kehidupan bangsa tersebut, mutu pendidik merupakan salah satu kompenen yang mempunyai peran sangat penting dalam proses pembelajaran. Salah satu upaya untuk meningkatkan mutu pendidikan di kampus adalah dengan cara perbaikan proses belajar mengajar atau pembelajaran. Berbagai konsep dan wawasan baru tentang pembelajaran di kampus telah muncul dan berkembang seiring pesatnya ilmu pengetahuan dan teknologi. Dosen sebagai pendidik yang menduduki posisi strategis dalam pengembangan sumber daya manusia, dituntut untuk terus mengikuti perkembangan konsep-konsep baru dan tujuan dalam dunia pendidikan ( Suryosubroto, 2002).

Perkembangan konsep-konsep baru dalam dunia pendidikan, tidak terlepas dari peningkatan proses pembelajaran melalui metode pembelajaran yang inovatif dan penilaian terhadap peningkatan tiga ranah yaitu; kognitif, afektif dan psykomotorik yang akan disesuaikan dengan materi dan submateri yang akan dipelajari dalam perkuliahan. Perkuliahan pada mata kuliah Vertebrata, tidak cukup hanya penguasaan terhadap teorinya saja, melainkan harus melakukan perkuliahan praktikum yang memperdalam tingkat pemahaman dan penguasaan terhadap organ dan sistem jaringan dari hewan Vertebrata terutama pada ilmu pembedahan yang didahului pengenalan dan fungsi alat, bahan serta media yang digunakan.

Menurut Hastuti (2013), pembelajaran biologi tidak hanya dapat dilakukan di dalam kelas. Ciri dari pembelajaran biologi adalah adanya kegiatan praktikum baik di Laboratorium maupun di alam. Banyak konsep biologi yang kompleks sehingga diperlukan suatu kegiatan untuk memudahkan siswa dalam memahami konsep tersebut. Kegiatan praktikum sangat sesuai untuk memfasilitasi siswa belajar melalui pengalaman langsung. Praktikum memberikan kesempatan kepada siswa untuk mendapatkan gambaran dalam keadaan yang nyata tentang apa yang diperoleh dalam teori dan terjadi kontak inderawi. Selain itu, dalam kegiatan praktikum siswa tidak sekedar mengamati secara langsung tetapi harus menghayati, terlibat langsung dalam perbuatan dan bertanggung jawab terhadap hasilnya.

Berdasarkan hasil nilai Kriteria Klasikal Minimum, pada semester IV Program Studi 
Pendidikan Biologi STKIP Bima tahun ajaran 2016/2017, dari mata kuliah Vertebrata menunjukkan bahwa nilai mahasiswa masih dibawah standar nilai KKM. Berdasarkan hasil observasi dari dosen pengampu mata kuliah, rendahnya nilai tersebut disebabkan beberapa faktor yaitu; menurun nilai tes, kurang keseriusan mahasiswa saat pembedahan, waktu praktikum kurang, mahasiswa sering datang terlambat, mahasiswa kurang teliti pada pengenalan organ dan sistem jaringan pada anatomi hewan yang di bedah.

Beberapa faktor penyebab menurunnya nilai mata kuliah Vertebrata tersebut, akan dijadikan indikator penilaian pada lembar sikap ilmiah dan hasil belajar kognitif pada penelitian ini, sehingga akan mendapatkan kejelasan instrumen yang akan di nilai pada proses pembelajaran.

Berdasarkan latar belakang yang telah diuraikan di atas, penulis ingin mendalami ilmu kependidikan yang dituangkan dalam suatu karya dengan judul: Upaya peningkatan hasil belajar kognitif melalui pembelajaran berbasis praktikum ditinjau dari kemampuan akademik mahasiswa."

\section{METODE}

Jenis penelitian yang digunakan dalam penelitian ini adalah penelitian tindakan kelas (PTK). Menurut Sugyono (2010), penelitian tindakan kelas (PTK) merupakan suatu pencermatan terhadap kegiatan belajar dan terjadi dalam sebuah kelas secara bersamaan. Penelitian tindakan kelas ini dilaksanakan melalui tahapan siklus dengan empat langkah proses pembelajaan yaitu tahap perencanaan, tindakan, observasi/evaluasi dan refleksi. Penelitian ini dilakukan dengan pendekatan persentase secara niklai ketuntasan idividu dan klasikal dengan mengukur nilai dari hasil belajar kognitif dan dilanjutkan dengan pendekatan kuantitatiff dengan rumus N-Gain. Tempat penelitian Penelitian ini dilaksanakan di STKIP Bima pada prodi pendidikan Biologi Jl. Tendean Kel. Mande Kota Bima.Waktu penelitian dilakukan pada semester genap tahun ajaran 2017/2018, selama 4 bulan mulai dari bulan April sampai bulan Agustus 2018. Subyek penelitian adalah mahasiswa semester IV kelas A dengan jumlah 30 orang, dengan pembagian jumlah mahasiswa yang perempuan sebanyak 20 orang dan yang lakilaki 10 orang. Instrumen dalam penelitian ini adalah: 1) Tes adalah serentetan pertanyaan atau latihan serta alat yang digunakan untuk mengukur pengetahuan intelegensi, kemampuan atau bakat yang dimiliki individu atau kelompok. Adapun bentuk tesnya secara tertulis berupa soal-soal pilihan ganda sebanyak 20 nomor pada mata kuliah Vertebrata materi tentang praktikum hewanhewan vertebrata, morfologi, dan fisiologi hewan Vertebrata.2) Lembar observasi ini 
merupakan sebagai pelengkap saja pada instrumen penelitian ini, dengan tujuan untuk mengetahui keterlaksanaan Satuan Acara Perkuliahan (SAP) melalui pembelajaran berbasis Praktikum, maka dalam penelitian ini dibuatkan instrumen berupa lembar observasi yang berbentuk check list $(\sqrt{ })$ yang berisi indikator langkah-langkah pembelajaran berbasis Praktikum.Teknik Pengumpulan Data yaitu dengan melakukan pretest dan posttest pada setiap siklus I dan siklus II dari soal pilihan ganda dengan materi praktikum hewan vertebrata, menghitung nilai tes belajar secara persentase dengan berpedoman pada rumus ketuntasan individu dan klasikal (Trianto 2009). Untuk mengetahui selisih persentase hasil pretest dengan posttest, data variabel terikat dilakukan Uji N- Gain (Nasir, 2015).

\section{HASIL DAN PEMBAHASAN}

Penelitian tindakan kelas ini dilaksanakan dalam II siklus. Subjek penelitian adalah mahasiswa semester VI kelas A yang berjumlah 30 orang yang terdiri dari 10 orang laki-laki dan 20 orang perempuan. Sebelum dilakukan proses pembelajaran, didahului pemberian prettes untuk melihat sejauh mana tingkat pemahaman mahasiswa terhadap materi vertebrata sebelum di ajarkan. Adapun hasil prettes tersebut sebagai berikut:
Tabel1.Data Prettes Belajar mahasiswa semester VI kelas A

\begin{tabular}{|l|c|c|c|c|c|}
\hline No & $\begin{array}{l}\text { Jumlah } \\
\text { mahasiswa }\end{array}$ & $\begin{array}{l}\text { Jumlah } \\
\text { total } \\
\text { nilai }\end{array}$ & Rerata & $\begin{array}{l}\text { Nilai } \\
\text { terendah }\end{array}$ & $\begin{array}{l}\text { Nilai } \\
\text { tertinggi }\end{array}$ \\
\hline 1 & 30 & 1300 & 43,33 & 20 & 70 \\
\hline
\end{tabular}

Adapun hasil evaluasi belajar pada

Siklus I, dapat terlihat pada tabel dibawah ini:

Tabel 2. Data Evaluasi hasil belajar kognitif mahasiswa semester IV kelas A pada Siklus I.

\begin{tabular}{|l|c|c|c|c|c|}
\hline No & $\begin{array}{l}\text { Jumlah } \\
\text { mahasiswa }\end{array}$ & $\begin{array}{l}\text { Jumlah } \\
\text { total } \\
\text { nilai }\end{array}$ & Rerata & $\begin{array}{c}\text { Nilai } \\
\text { Mahasiswa } \\
\text { Tuntas }\end{array}$ & $\begin{array}{c}\text { Nilai } \\
\text { Mahasiswa } \\
\text { belum } \\
\text { Tuntas }\end{array}$ \\
\hline 1 & 30 & 1730 & 57,67 & 16 & 14 \\
\hline
\end{tabular}

Berdasarkan Tabel 2, menunjukkan bahwa 14 orang mahasiswa belum memperoleh nilai ketuntasan belajar individu, sehingga pada siklus I belum mencapai nilai ketuntasan Klasikal yang di standarkan sebesar $\geq 85 \%$, karena dari jumlah 30 siswa, yang tuntas belajar hanya 16 orang, sehingga nilai Ketuntasan Klasikal masih dibawah standar, karena nilainya hanya $53,33 \%$, dan perlu dilanjutkan pada pembelajaran Siklus II.

\section{Refleksi Siklus I.}

Berdasarkan kekurangan atau kelemahan hasil Siklus I tersebut, maka tindakan perbaikan, yang harus dilakukan adalah sebagai berikut: 1). Guru harus memperhatikan waktu dalam interaksi dengan siswa, 2). Guru harus memberikan batas waktu kepada siswa untuk menjawab sosl-soal, 3). Guru harus membimbing siswa untuk membuat kesimpulan kedalam bahasanya 
sendiri dan memberikan umpan balik kepada siswa dengan cara memberikan pertanyaan secara lisan, dari beberapa orang siswa dengan tujuan untuk memperkuat ingatan siswa terhadap materi yang baru dibahas, dan 4). Pada saat menutup pelajaran guru selalu memberikan pekerjaan rumah, agar siswanya termotivasi belajarnya dirumahnya.

Setelah di adakan evaluasi hasil belajar kognitif dari tes siklus II pada pokok bahasan organ Sistem jaringan hewan Vertebrata, dengan pembelajaran pembedahan hewanhewan vertebrata, maka dari hasil evaluasi belajar mahasiswa di peroleh data seperti tabel dibawah ini.

Tabel 3.Data Posttes Hasil Belajar Siklus II

\begin{tabular}{|c|c|c|c|c|c|c|}
\hline $\begin{array}{c}\text { Jumlah } \\
\text { siswa }\end{array}$ & $\begin{array}{c}\text { Total } \\
\text { skor }\end{array}$ & $\begin{array}{c}\text { Rata- } \\
\text { rata }\end{array}$ & $\begin{array}{c}\text { Siswa } \\
\text { tuntas }\end{array}$ & $\begin{array}{c}\text { Siswa } \\
\text { tidak } \\
\text { tuntas }\end{array}$ & $\begin{array}{c}\text { Nilai } \\
\text { tertinggi }\end{array}$ & $\begin{array}{c}\text { Nilai } \\
\text { terendah }\end{array}$ \\
\hline 30 & 2260 & 75,33 & 29 & 1 & 90 & 50 \\
\hline
\end{tabular}

Berdasarkan Tabel. 3 menunjukkan bahwa 29 orang mahasiswa memperoleh nilai ketuntasan belajar individu, dengan nilai ratarata 75,33 yang berarti bahwa mahasiswa semester IV kelas A telah mencapai nilai ketuntasan Klasikal sebesar 96,66 \% pada Siklus II, dengan demikian proses pembelajaran dengan berbasis praktikum sangat meningkat hasil belajar kelas A.

Data hasil belajar kognitif sebagai nilai hasil semester mata kuliah vertebrata dideskripsikan sebagai peningkatannya pada nilai kemampuan akademik akhir adalah jumlah mahasiswa yang memperoleh nilai kemampuan akademik tinggi sebanyak 14 orang atau $46,67 \%$, sedang sebanyak 13 orang atau $43,33 \%$, dan rendah hanya 3 orang atau 10\%. Hal ini menunjukkan bahwa terjadi peningkatan nilai mahasiswa berkemampuan akademik awal dari dari semester III (ganjil) ke nilai semester IV (Genap). Perbandingan jumlah mahasiswa yang bernilai kemampuan akademik tinggi,sedang, dan rendah tersebut dapat terlihat pada Tabel 4. sebagai berikut.

Tabel 4. Data Hasil Belajar Kognitif Berdasarkan Kemampuan Akademik

\begin{tabular}{|c|l|l|l|l|}
\hline No & $\begin{array}{l}\text { Kemampuan } \\
\text { Akademik } \\
\text { Awal }\end{array}$ & N & $\begin{array}{l}\text { Kemampuan } \\
\text { Akademik } \\
\text { Akhir }\end{array}$ & N \\
\hline 1 & Tinggi & $7(23,33 \%)$ & Tinggi & $14(46,67 \%)$ \\
\hline 2 & Sedang & $12(40 \%)$ & Sedang & $13(43,33 \%)$ \\
\hline 3 & Rendah & $11(36,67 \%)$ & Rendah & $3(10 \%)$ \\
\hline
\end{tabular}

Berdasarkan hasil uji analisis N-Gain dengan menganalisis data variabel terikat yaitu hasil evaluasi belajar kognitif dari prettes dan posttes untuk mengetahui selisih porsentase peningkatan hasil belajar kognitif. Adapun hasil analisi dengan uji N-Gain tersebut, dapat dilihat pada tabel 4.5 sebagai berikut :

Tabel. 5. Data hasil Uji N-Gain

\begin{tabular}{|c|c|c|c|c|}
\hline No & $\begin{array}{c}\text { Jumlah } \\
\text { Siswa }\end{array}$ & Porsentase & $\begin{array}{c}\text { Kriteria N- } \\
\text { Gain }\end{array}$ & Ket. \\
\hline 1 & 14 & $46,67 \%$ & N-Gain $>0,70$ & Tinggi \\
\hline 2 & 16 & $53,33 \%$ & $\begin{array}{c}0,30 \leq \mathrm{N}- \\
\text { Gain } \leq 0,70\end{array}$ & Sedang \\
\hline 3 & 0 & - & N-Gain $<0,30$ & Rendah \\
\hline
\end{tabular}




\section{Refleksi akhir}

Menurut hasil analisis evaluasi hasil belajar mahasiswa dan observasi keterlaksanaan pembelajaran berbasis praktikum pada siklus II, hasil yang di peroleh telah memenuhi indikator kerja dan berkatogori sangat baik, yang berarti pembelajaran berbasis praktikum sudah dilakukan dengan baik dan benar dan hasil evaluasi belajar memperoleh nilai rata-rata kelasnya adalah 75,33 dan siswa kelas IV A telah memenuhi ketuntasan belajar individunya, sehingga persentase ketutasan belajar klasikal sebesar 96,66\%. Peningkatan nilai hasil belajar siswa pada siklus II, menunjukkan bahwa dengan menggunakan pembelajaran berbasis praktikum dapat meningkatkan hasil belajar siswa secara efektif, dengan pelaksanaan tindakan yang semakin baik dan proses belajar mengajar berjalan dengan lancar serta siswa sudah terlihat sangat antusias dalam proses belajarnya, sehinga pelaksanaan tindakan pembelajaran telah di laksanakan dengan baik.

\section{KESIMPULAN}

Berdasarkan hasil penelitian dan pembahasan yang telah di uraikan di atas, dapat disimpulkan bahwa hipotesis Ho ditolak dan Ha diterima yaitu: 1) Ada peningkatan hasil belajar kognitif melalui pembelajaran berbasis praktikum pada mahasiswa semester
IV kelas A Program Studi Pendidikan Biologi STKIP Bima tahun ajaran 2017/2018. 2) Ada peningkatan hasil belajar kognitif ditinjau dari kemampuan akademik mahasiswa melalui pembelajaran berbasis praktikum pada mahasiswa semester IV kelas A Program Studi Pendidikan Biologi STKIP Bima tahun ajaran 2017/2018Peningkatan hasil belajar siswa tersebut, terlihat pada siklus II, dimana peningkatan hasil ketuntasan belajar siswa secara klasikal mencapai 96,66\%. Pencapaian nilai hasil belajar yang tinggi tersebut sudah melewati nilai standar ketuntasan klasikal $\geq$ $85 \%$, dan berdasarkan uji N-Gain terjadi peningkatan hasil belajar kognitif sebanyak 29 orang mahasiswa yang terdiri 10 orang berkategori nilai tinggi dan 19 orang berkategori nilai sedang dari 30 orang mahasiswa.

Hasil penelitian inipun sesuai dengan teori menurut Khamidah dan Aprilia (2014) yang menyatakan bahwa Praktikum akan lebih efektif untuk meningkatkan keahlian siswa dalam pengamatan dan meningkatkan keterampilan serta sebagai sarana berlatih dalam menggunakan peralatan. Selain itu dengan praktikum siswa dapat mengembangkan rasa ingin tahu, aktif, kreatif, inovatif, serta menumbuhkan kejujuran ilmiah Menurut Hidayati (2012), melalui praktikum siswa juga dapat mempelajari sains dan pengamatan langsung terhadap gejala-gejala 
maupun proses-proses sains, dapat melatih keterampilan berfikir ilmiah, dapat menanamkan dan mengembangkan sikap ilmiah, dapat menemukan dan memecahkan berbagai masalah baru melalui metode ilmiah dan sebagainya. Kemampuan ini bisa dikembangkan melalui kegiatan praktikum.

\section{DAFTAR PUSTAKA}

Direktorat Akademik Ditjen Dikti. (2008). Buku Panduan Pengembangan Kurikulum Berbasis Kompetensi Pendidikan Tinggi. Jakarta: Sub Direktorat KPS.

Fahruddin, 2014. Pengaruh model pembelajaran kooperatif terhadap hasil belajar kognitif ditinjau dari kemampuan akademik mahasiswa STKIP Bima. Jurnal EURADIO Vol.2.no.1. 2014.UNBRA

Hastuti, A. (2013). Penerapan Pembelajaran Berbasis Praktikum untuk Meningkatkan Motivasi dan Hasil Belajar Biologi Materi Pokok Sistem Reproduksi Manusia. Skripsi. Yogyakarta: Jurusan Pendidikan
Biologi Fakultas Sainstek UIN Sunan Kalijaga.

Khamidah, N dan Aprilia, N. (2014). Evaluasi Program Pelaksanaan Praktikum Biologi Kelas XI SMA Se-Kecamatan Umbulharjo Yogyakarta Semester II TahunAjaran 2013/2014. JUPEMASIPBIO 1(1): 5-8.

Nasir, M., \& Jufri, A. W. (2015). Pengembangan Perangkat Pembelajaran Model 5E untuk Meningkatkan Kemampuan Berpikir Kritis Siswa. Jurnal Penelitian Pendidikan IPA, 1(2)

STKIP Bima, (2013). Buku Pedoman Akademik Sekolah Tinggi Keguruan dan Ilmu Pendidikan. (STKIP Bima). Edisi 2013

Sugiyono, 2013. Metode Penelitian Pendidikan Pendekatan Kuantitatif, Kualitatif, dan R\&D. Bandung: Alfabeta.

Suryosubroto, B. (2002). Pembelajaran Berbasis Praktikum Pada Konsep Pembelajaran Invertebrata Untuk Pengembangan Sikap Ilmiah Siswa. Skripsi (tidak dipublikasikan). IKIP Mataram.

Purwanto, 2013. Evaluasi Hasil Belajar.

Yogyakarta: Pustaka Pelajar. 